\title{
LISTA PRENUMERATORÓW „IZYS POLSKIEJ”
}

„Izys Polska, czyli Dziennik umiejętności, wynalazków, kunsztów i rękodzieł, poświęcony krajowemu premysłowi tudzież potrzebom wiejskiego gospodarstwa" (jak to podówczas bywało - wbrew tytułowi nie dziennik lecz miesięcznik) ukazywać się zaczęła w Warszawie w roku 1820 , przestała zaś wychodzić w roku 1828 . W zamierzeniach inicjatora i pierwszego wydawcy (Gracjan Korwin, inwalida, były podprefekt w Staszowie, urodzony 1779 , zmarhy 1821) było wydawanie co miesiąc jednego zeszytu; cztery zeszyty tworzyć miały tom. W sumie wyszło jednak 18 tomów - za następcy Korwina, Antoniego Lelowskiego, odstąpiono od pierwotnych zamiarów.

Zamiary co do treści jednak utrzymano; pismo istotnie zawierało, jak zapowiadano, wiadomości z zakresu nauk przyrodniczych, opisy zagranicznych fabryk, wiadomości pożyteczne dla rolnictwa, gospodarstwa domowego i przemysłu, omówienia literatury technicznej i gospodarczej polskiej i obcej, wiadomości o wynalazkach i patentach, opisy sprzętów i urządzeń wytwarzanych w kraju i za granica. Uzupełnieniem tekstu były ryciny, głównie rysunki techniczne. Pismo dostarczało więc aktualnych informacji technicznych i gospodarczych i zdawać by się mogło, dobrze dostosowane było do potrzeb $w$ dobie początków nowej techniki uprawy roli, trwających przemian społecznych na wsi i rozpoczynającego się uprzemysłowienia w kraju. Zmiana wydawcy przynajmniej przez pierwsze lata redaktorstwa Lelowskiego nie przyniosła zmian, które mogłyby zależeć od wydawnictwa.

Dzisiejszy czytelnik „Izys Polskiej” może jednak spojizeć na to pismo nie tylko w celu weryfikacji zamiarów jego wydawcy. Może też zapytać, jakie światło rzuca ono nie na dziedzinę, której było poświęcone, lecz na inne, pozornie odległe pola. Obiektem obserwacji stać się zaś może lista prenumeratorów, gdyż dotychczas piszący o tym czasopiśmie, nie wyłączając jego monografisty, Wactawa Szuberta, liście tej poświęcili tylko mimochodem nieco uwagi.

Wykaz taki, listę prenumeratorów, podobnie jak inne czasopisma publikowała również „Izys Polska” przy każdym tomie. Lista już choćby ze względu na swe miejsce - na początku tomu - była szczególnie narażona na zniszczenie $w$ nieoprawnych tomach. Niekiedy też listy przed oprawieniem tomu usuwano. W żadnym z kilku badanych egzemplarzy kompletnych 18 tomów nie ma kompletu list prenumeratorów. Lista zawiera zazwyczaj imię i nazwisko prenumeratora, jego jeśli miał - stopień wojskowy, stanowisko lub zawód, tytuł rodowy, miejsce zamieszkania, liczbę prenumerowanych egzemplarzy, jeśli było ich więcej niż jeden. W początkowych tomach układ listy był alfabetyczny, później częściowo usystematyzowany rzeczowo (np. szkoły). Sądzić można, że listy stanowią kompletne wykazy prenumeratorów, tzn. zawierają wszystkich lub prawie wszystkich, którzy 
otrzymywali pismo. A przemawia za tym przypuszczeniem nie tylko stosowana podówczas zasada rozpowszechniania jedynie przez prenumeratę, ale także i to, że tam gdzie zdarzaly się opuszczenia (niewielkie) wydawca uważał się za zobowiązanego do uzupełnień i sprostowań. Tak więc w roku 1820 zamieszczał dodatkowo 5 nazwisk prenumeratorów, poprzednio w spisie pominiętych, thumaczył się też, że „(...) nazwiska Prenumeratorów, których (...) pocztamty nie nadesłały, nie mogły być umieszczone". Troskę o dokładność listy prenumeratorów posuwał tak daleko, że w innym tomie wyjaśniał, iż "(..) nazwiska będą umieszczone tak jak je nadesłały pocztamty", a więc rozumieć należy, według tam stosowanej pisowni. Jak widać szło już nie tylko o dokładność liczby, ale i o brzmienie. W tym stanie rzeczy listę prenumeratorów można uznać za źródło dokładne lub bardzo bliskie dokładności i wiarygodne. Wynika z niej, że liczba prenumerowanych egzemplarzy przedstawiała się następująco:

Tab. 1. Prenumerata „Izys Polskiej”

\begin{tabular}{|l|c|c|c|c|c|c|c|c|}
\hline Rocznik & $1820 / 21$ & $1821 / 22$ & $1822 / 23$ & $1823 / 24$ & $1824 / 25$ & $1825 / 26$ & $1826 / 27$ & $1827 / 28$ \\
\hline Liczba egz. & 317 & 327 &. & 315 & 300 & 301 & 296 &. \\
\hline
\end{tabular}

Jak widać, wahania były niewielkie, nie przekraczały $10 \%$ nakładu wykazujacego tendencję zniżkową. Zdawałoby się więc, że zapewne taka była chłonność rynku czytelniczego.

Wyznaczał ją m.in. koszt prenumeraty: rocznie bez kosztów pocztowych, a więc dla odbierających pismo w redakcji, wynosił on 54 zł, z przesyłką w kraju 60 zł, za granicą więcej o koszt poczty. Suma ta stawiała poza kręgiem czytelników przede wszystkim umiejących wprawdzie czytać, ale należących do „klas niższych”. Dla umożliwienia porównań przypomnijmy, że wyrobnikom płacono podówczas do 1 zł dziennie, rzemieślnik w Warszawie zarabiał 2-4 zł dziennie. Miesięcznik poświęcony rękodziełom był już ze względu na cenę niedostępny większości rękodzielników. Niższy urzędnik w magistracie warszawskim zarabiał 50-70 zł miesięcznie, urzędnik średniej rangi do 200 zł. Gdy kilka lat przed ukazaniem się pierwszego zeszytu „Izys Polskiej” utworzono w Warszawie Towarzystwo Dobroczynności, wysokość składki członkowskiej określono na 6 zł miesięcznie. Członkostwo zgłosiło nieco ponad 200 osób, tylu było gotowych do ponoszenia wydatku niewiele wyższego niż prenumerata „Izys”, i rzecz jasna nie było tu rękodzielników.

Czy wydawca zdawał sobie sprawę z rozdźwięku między podtytułem i rzeczywistością? Powszechne było podówczas niedostrzeganie granicy pomiędzy przemysłem i rzemiosłem. Wizja przemysłu jako „rzemiosła, tylko w większym rozmiarze" przesłaniała granice między tymi dwoma obszarami. Wszak sam Stanisław Staszic, wysoki urzędnik zajmujący się przemysłem, taką miał wizję miast przemysłowych: ulice obudowane domkami przędzarzy, tkaczy i farbiarzy, za tymi jednorodzinnymi domkami niewielkie poletka, na których każdy z przędzarzy lub farbiarzy 
dla siebie uprawiać miał len i rośliny farbiarskie i w ten sposób zapewnić zaopatrzenie w surowce. Tak też pierwotnie planowano Łódź, Zgierz i inne miasta tego regionu. Obok tych jednoosobowych zakładów powstawały także większe manufaktury o tej samej jednak technice produkcji. Nic więc dziwnego, że do takich właśnie bogatszych producentów mógł wydawca adresować „Izys Polską”, gdy mówił o rękodzielnikach.

Kto więc prenumerował „Izys Polską"? W pienwszym roku istnienia miesięcznika byli to:

Tab. 2. Prenumeratorzy „Izys Polskiej” w roku $1820 / 21$ w procentach prenumerowanej liczby egzemplarzy

\begin{tabular}{|l|c|}
\hline Grupa prenumeratorów & Procent prenumerowanych egz. \\
\hline Urzędnicy & 28,4 \\
Obywatele ziemscy & 20,5 \\
Adwokaci, sędziowie, notariusze & 12,6 \\
Wojskowi & 10,4 \\
Profesorowie i nauczyciele & 3,2 \\
Kupcy i przemyslowcy & 2,2 \\
\hline
\end{tabular}

Resztę stanowiły różne drobne grupy, jak dzierżawcy, duchowni, kilka bibliotek, kilka innych instytucji i inni, razem ok. $15 \%$. Około $8 \%$ stanowiły osoby, które w spisie określono przez samo nazwisko, brak więc formainych i jednorodnych przesłanek, pozwalających zakwalifikować je do którejkolwiek z określonych grup.

Struktura ta budzi zdziwienie. Wyjaśnienie absencji rzemiosła (zbyt wysoka cena) dotyczyć może także części przemystowców, byli jednak wśród nich także tacy, których z pewnością stać było na prenumeratę, a przecie są w spisie tak słabo reprezentowani. Powiększa ten znak zapytania jeszcze bardziej informacja, że w grupie „kupcy i przemystowcy” jest kilku księgarzy - dla reszty pozostaje więc bardzo niewiele. Kontrast stanowi wielka grupa zw. „obywatele ziemscy". Należało by ją jeszcze powiększyć o część grupy „brak danych”, gdyż niektóre osoby tam zaliczone z powodu braku innych danych oprócz nazwiska, nosiły jednak nazwiska znaczące (Lanckorońska, Poletyło, Oskierka itp.). „Obywatele ziemscy”, podobnie jak przemysłowcy, byli naturalnymi czytelnikami miesięcznika, dotyczył on przecież samych podstaw ich egzystencji. Jakże odmienne były ich zachowania. Zrozumiały jest także, niewielki zresztą, udział profesorów i nauczycieli.

Na pierwszy rzut oka zaskakuje liczebność urzędników, tym bardziej, że ponadto pewna ich liczba kryć się może (podobnie jak obywateli ziemskich) w grupie „brak danych”. Przypominając koszty prenumeraty i wysokość urzędniczych poborów trudno oprzeć się przypuszczeniu, że nie są to przeciętni urzędnicy. Tak jest istotnie - jest wśród nich namiestnik Zajączek, senator Nowosilcow, ministrowie 
stojący na czele komisji rądowych, dyrektorzy wydziałów w tych komisjach, szefowie innych instytucji centralnych, prezesi komisji wojewódzkich, a spoza Królestwa namiestnik Radziwił z Poznania, prezes Senatu miasta Krakowa, Wodzicki i inni dygnitarze. Na czele całej listy w roku 1821 figurował car, który na prośbę Korwina najmiłościwiej zgodził się prenumerować 30 egzemplarzy, przeznaczając je na potrzeby „uboższych instytutów naukowych”. Jest jednak znaczna grupa urzędników średniej rangi, co dziwniejsze, zatrudnionych na stanowiskach nie mających wiele wspólnego z tematyką „Izys Polskiej”.

Nieco podobnie przedstawiała się grupa wojskowych. Byli to generałowie, dowódcy dywizji i brygad, oficerowie od majora poczynając, kilku emerytowanych wyższych oficerów.

Adwokaci i notariusze zarabiali na ogół nieźle, ze względów finansowych nie mieli przeszkód, dziwne jednak, że liczni prenumerowali pismo o tematyce tak odległej od ich zawodowych zainteresowań.

W sumie lista z początkowego okresu ukazywania się pisma jest wyraźnie ekskluzywna, elitarna, wykazuje też w niektórych przypadkach brak zależności między zawodowymi potrebami prenumeratora i tematyką prezentowaną w piśmie. Byli wśród abonentów tacy, którzy brali miesięcznik, bo dotyczył ich zawodowych potrzeb, byli i tacy, którzy mimo braku takiej zbieżności pozostawali przy prenumeracie. Wydawać by się mogło, że motyw ich zainteresowań pismem leżał poza granicą zawodu. Czy była to presja urzędu zainteresowanego upowszechnieniem wiadomości gospodarczych i technicznych przynoszonych przez "Izys” i zapewne pożytecznych przy realizacji rządowego programu uprzemysłowienia kraju? Jeśli prenumerata była dobrze widziana przez zwierzchnictwo, to choć zamiar przypodobania się władzy i względy prestiżowe były z pewnością zbyt słabe, by same mogły skłonić kogokolwiek do prenumeraty, jednak mogły umacniać abonentów w ich decyzji. Czy nie działal tu pewien snobizm i dziś czasem możliwy do obserwowania? Czy nie działały w tym samym kierunku jakieś inne zachęty?

Nagle w latach $1821 / 22$, a więc $w$ drugim i trzecim roku ukazywania się pisma zmieniły się uderzająco proporcje wśród abonentów. Oto one:

Tab. 3. Prenumeratorzy „Izys Polskiej” w procentach prenumerowanej liczby egzemplarzy

\begin{tabular}{|l|c|c|c|}
\hline \multirow{2}{*}{} & \multicolumn{3}{|c|}{ Liczba prenumerowanych egzemplarzy } \\
\cline { 2 - 4 } & $1820 / 21$ & $1821 / 22$ & $1826 / 27$ \\
\hline Instytucje & 11,1 & 30,3 & 76,3 \\
Osoby & 88,9 & 69,7 & 23,7 \\
w tym & & & \\
Urzednicy & 28,4 & 17,1 & 3,8 \\
Obywatele ziemscy & 20,5 & 20,2 & 8,1 \\
Adwokaci, sędziowie, notariusze & 12,6 & 1,2 & 0,7 \\
Wojskowi & 10,4 & 8,9 & 3,3 \\
Profesorowie i nauczyciele & 3,2 & 4,3 & - \\
Kupcy i przemystowcy & 2,2 & 3,1 & 1,4 \\
Inni & 3,7 & 4,0 & 0,7 \\
Brak danych & 7,9 & 10,9 & 5,7 \\
\hline
\end{tabular}


Jak widać prenumeratę przejęły instytucje. Zapewne w poszukiwaniu sposobów uniknięcia ponoszenia kosztów prenumeraty niektórzy urzędnicy, prawnicy i wojskowi - zapewne wysocy rangą mieli takie możliwości - polecili podległym sobie instytucjom zaprenumerować „Izys Polską. Prawdopodobnie mieli więc pismo na koszt instytucji. W tym przypuszczeniu utwierdzać może także praktyka zastosowana przez komisje wojewódzkie. Przejęły one na siebie koszty egzemlarzy przeznaczonych dla podległych im instytucji w obwodach i same opłacały prenumeratę. Zdawać by się mogło, że idzie tu o neutralny zabieg organizacyjny, dlaczego jednak zabieg ten podjęto, dlaczego tak radykalnie malała liczba obywateli ziemskich abonujących pismo (1820 rok $-20,5 \%, 1827$ rok $-8,1 \%)$, jeszcze bardziej zaś liczba prawników (12,6\% i 0,7\%)? Dlaczego w „lzys Polskiej” pojawiały się bez wyraźnego powodu informacje w rodzaju tej z roku 1823, że pismo „(...) wychodzi i wychodzić będzie dzięki opiece władz", jakby trzeba było wątpiących upewnić, że jest dobrze widziane? Na czym ta opieka miała polegać?

Imię tytułowej bogini miało już w Warszawie swój kontekst. W kwietniu 1780 roku z warszawskiej loży wolnomularskiej „Katarzyna pod gwiazdą Północy” wydzielono polskojęzyczną lożę „Świątynia lzys”. Przechodziła ona różne koleje, kilkakrotnie zawieszała działalność w latach szczególnych napięć politycznych, manifestowała też uczucia obywatelskie. Gdy po kolejnej pauzie podjęto próbę wznowienia loży w roku 1804, centrala berlińska nie zgodziła się na przywrócenie dawnej nazwy, od kwietnia 1805 loża działała więc pod nazwą „Świątynia Mądrości", dawna nazwa loży nie była więc tylko nazwą, miała zapewne i inne znaczenie. Powrócono do niej w roku 1809, a po następnej przerwie (w roku 1812 „(...) na skutek oddalenia się wielu braci") od października 1813 roku rozpoczął się okres aktywności. Pojawiły się oznaki nowego: insygnia masońskie uzupełniano wstęgami o barwach narodowych, organizowano „zebrania patriotyczne”, rysować się zaczynało wolnomularstwo narodowe. Loże za pomocą czasopism, na które miahy wpływ przez braci w redakcjach (,Tygodnik Polski i Zagraniczny”, „Gazeta Codzienna, Narodowa i Obca”, „Dekada Polska”, „Orzeł Biahy”, „Momus” i inne) urabiały opinię publiczną dla popierania postępowców w sejmie.

Czy dziennik poświęcony kunsztom miał z tym cokolwiek wspólnego? Pokrewieństwo nazw loży i pisma jest oczywiste. Loża od dawna przejawiała zainteresowania rozwojem nauk i postępem technicznym. Jeszcze w roku 1781 powstały dwa projekty opracowania encyklopedii i w „Świątyni Izys” dyskutowano nad nimi. Loża miała wpływy w dziedzinie oświaty, a uległy one umocnieniu, gdy na czele tego resortu stał Stanisław Kostka Potocki, Wielki Mistrz. W redakcji „Izys Polskiej” i wśród jej najbliższych współpracowników było kilku masonów. Do bliższych współpracowników należeli, bądź związani z wydawaniem „Izys Polskiej” byli: księgarz Natan Glücksberg, który wraz z synem Krystianem zajmował się rozpowszechnianiem czasopisma w Warszawie, Krzemieńcu i Kijowie, sztycharz Samuel Münchheimer, dyrektor drukarni rządowej Konstanty Dąbek, redaktor "Wandy” Dominik Lisiecki, Piotr Łubieński, Wincenty Szczucki. Wielu współpracowników należało do „Świątyni lzydy”. Pismo zajmowało się szerokimi problemami społeczno-gospodarczymi, mogło więc wraz z innymi być narzędziem służącym urabianiu opinii, żadnej formalnej zależności jednak nie było. Wśród trzystuosobowej rzeszy 
prenumeratorów „|zys" dwie najsilniejsze grupy społeczne - urzędnicy i obywatele - mieli prawie dokładnie taki sam udział, jak w całej populacji masonerii warszawskiej:

\begin{tabular}{|l|c|c|}
\hline & $\begin{array}{c}\text { Wśród braci } \\
\text { W lożach warszawskich }\end{array}$ & $\begin{array}{c}\text { Wśród prenumeratorów } \\
\text { "Izys Polskiej" }\end{array}$ \\
\hline Procent urzędników i obywateli & 46,5 & 48,8 \\
\hline
\end{tabular}

Uderzająca zbieżność dwu liczb nie świadczy jednak jeszcze o tak daleko idącej współzależności, wszak na każdą z tych liczb składać się mogły także inne osoby. Tyle tylko, że w warunkach warszawskich grupa fachowych urzędników, a i obywateli stale mieszkających w mieście, nie były zbyt wielkie. Te same osoby występowały więc i jako abonenci i jako bracia i tworzyły w ten sposób dalsze powiązania między wolnomularstwem i dziennikiem. Wśród prenumeratorów „lzys Polskiej" - wysoko postawionych masonów - byli m.in.: Kazimierz Brodziński, Adolf Cichowski, Ksawery Drucki-Lubecki, Bruno Kiciński, Ksawery Kossecki, Amilkar Kosiński, Kajetan Koźmian, dwaj Krasińscy, Kazimierz Małachowski, Bogumił Światopełk-Mirski, Józef Orsetti, Ludwik Osiński, Franciszek Maksymilian Ossoliński, Ludwik Plater, Aleksander Pociej, Stanisław Kostka Potocki, Aleksander Rożniecki, dwaj Sapiehowie, Józef Kalasanty Szaniawski. „Izys Polską" abonował mason i późniejszy więzień Walerian Łukasiński, a także loże w Kaliszu, Wilnie i Poznaniu.

Wladze początkowo odnoszące się do wolnomularstwa z pewną tolerancją, $z$ upływem czasu zaczęły podejrzewać je o idee niepodległościowe i rewolucyjne. Wzrastające ogólne napięcia społeczne i rozwój konspiracji w całej Europie wywoływały pewną nerwowość w działaniach władz. Nowosilcow składał carowi alarmujące meldunki i wzywał namiestnika do podjęcia działań praktycznych. We wrześniu 1821 roku namiestnik wydał postanowienie nakazujące całej masonerii w Królestwie Polskim zaprzestać działalności. Wolnomularstwo pryjęło to postanowienie z zaskoczeniem - tak daleko idących restrykcji się nie spodziewano. Loże zajęły się przekazywaniem na cele charytatywne majątku ruchomego, nieruchomy miały przejąć władze. Członkowie zlikwidowanych lóż mieli zgodnie z następnym zarządzeniem podpisywać zobowiązania, że nie będą należeli do organizacji konspiracyjnych. Nastapiły rewizje, przesłuchania i aresztowania. Aresztowano i przesłuchiwano braci ze "Świątyni Izydy" także i później, między innymi w związku ze sprawą Dekabrystów i ze sprawą Towarzystwa Patriotycznego, nie zawsze przy tym jasne były przyczyny aresztowania. Niektórych od początku ogarnął popłoch, reagowali nerwowo, niektórzy zmierzali ku konspiracji.

W tym klimacie wystawienie w Teatre Wielkim w Warszawie we wrześniu 1822 roku opery Mozarta „Flet Czarodziejski czyli Tajemnice Izys" w odczuciu obu stron i podtytułem i treścią pełną symboliki i obrzędów nawiązujących do wolnomularstwa mogło zostać uznane za prowokację, z tego też powodu operę zdjęto. 
Być może związki między lożą „Świątynia lzydy" i pismem „Izys Polska” w tym pełnym napięć czasie również wydały się niebezpieczne i wpłynęły na postawę prenumeratorów; obywatelom kazały rezygnować, redakcji zapewniać, że nie jest źle widziana, a wysoko postawionym protektorom-masonom gwarantować prenumeratę przez podległe im urzędy. Tak już było do końca istnienia pisma, które wychodzić przestało, gdy ucichły na jakiś czas ostatnie, jakże trwale, echa masońskich młotków. 